\title{
Feeding strategy during pregnancy for ewes with a large litter size. 2. Effect on blood parameters and energy status
}

\section{H. EVERTS}

Research Institute for Livestock Feeding and Nutrition, P.O.Box 160, NL 8200 AD Lelystad, Netherlands

Received 7 December 1989; accepted 9 January 1990

\begin{abstract}
In six feeding trials glucose, beta-hydroxy-butyrate (BHB) and non-esterified fatty acids (NEFA) levels in the plasma of pregnant ewes were analysed. Glucose levels were affected by litter size after day 84 of pregnancy. An increase in litter size lowered the glucose level in plasma during the last phase of pregnancy. At day 141 a sharp rise in glucose level was observed. Ewes with acetonaemia showed after day 126 of pregnancy a significant lower glucose level. Also BHB and NEFA levels were affected by litter size in the last months of pregnancy. With increasing litter size BHB level increased more dramaticly than NEFA levels. Ewes with acetonaemia had significantly higher BHB and NEFA levels in the last month of pregnancy. Ewes on treatments with a higher metabolizable energy (ME) intake (rations with $60 \%$ of the energy originating from concentrates) showed a higher glucose, a lower BHB and a lower NEFA level in the last month of pregnancy than ewes on the control treatment (ration with $40 \%$ of the energy originating from concentrates). A lower incidence of acetonaemia on treatments with a higher energy intake was expected, but not observed. Probably, energy deficit is not the only factor inducing acetonaemia. With regression models the energy requirement of pregnant ewes with a body weight of about $85 \mathrm{~kg}$ during the last month of pregnancy was estimated. The ME requirement in $\mathrm{MJ}$ per day for a ewe with a single, twin, triplet, quadruplet and quintuplet was $13.0,15.9,17.1,18.4$ and 19.1, respectively. The estimated energetic efficiency of conceptus growth was about 0.16 .
\end{abstract}

Keywords: ewe, pregnancy, energy status, concentrates supply, blood parameters, litter size, acetonaemia

\section{Introduction}

Energy requirements of ewes during the last months of pregnancy are mostly presented for ewes with singles or twins. In some cases, also values for a larger litter size are shown. In Table 1, energy requirements of ewes during the last months of pregnancy are summarized. For ewes with twins a wide variation in ME requirement can be observed. One part of the variation is supposed to be due to differences in breeds, body weights of ewes and in environmental conditions. Another part of the 


\section{H. EVERTS}

Table 1. Energy requirements of pregnant ewes.

\begin{tabular}{lclll}
\hline Author & $\begin{array}{l}\text { Days of } \\
\text { pregnancy }\end{array}$ & $\begin{array}{l}\text { Body weight } \\
\text { of the ewe }(\mathrm{kg})\end{array}$ & $\begin{array}{l}\text { Litter } \\
\text { size }\end{array}$ & ME (MJ d-1) \\
CVB, 1988 & $90-145$ & 80 & 2 & 14.4 \\
Rattray, 1974 & $100-140$ & - a & 2 & $11.3>19.5$ b \\
Shevah \& Black, 1975 & $100-140$ & - & 3 & $12.3>21.6$ \\
MAFF, 1975 & $95-145$ & 65 & 2 & 16.7 \\
Sheehan et al., 1977 & $90-245$ & 70 & 2 & $9.2>16.5$ \\
ARC, 1980 & $90-145$ & 70 & 2 & 9.8 \\
NRC, 1985 & $105-145$ & 75 & 2 & $12.9>21.4$ \\
Russel, 1985 & $115-145$ & 70 & 2 & 18.4 \\
& $90-145$ & 70 & 3 & $11.0>17.8$ \\
INRA, 1988 & $90-145$ & 70 & 2 & $11.8>20.1$ \\
& $100-145$ & 70 & 3 & $10.5>17.0$ \\
& $100-145$ & 70 & & $10.8>18.4$ \\
\hline
\end{tabular}

a Not given.

$\mathrm{b}>=$ (gradually) increasing to.

variation can be due to the used indicator of energy status and the aimed level of this indicator. Lamb birth weight can be used as indicator. Russel et al. (1967) observed a relationship between energy intake and lamb birth weight, when ewes were underfed. Davies et al. (1971) reported similar results. However, Shevah \& Black (1975) showed no relation between lamb birth weight and energy intake of the ewe. Also body weight change of ewes is used as an indicator (Sheehan et al., 1977). However, this parameter is for ewes with different litter sizes a difficult parameter due to the fact that body weight gain during pregnancy is a net effect of intra-uterin gain and maternal body weight change.

Bowden (1971) indicated the use of NEFA and ketone bodies levels in the blood to estimate the energy status of ruminants. Russel (1977) discussed the use of glucose, NEFA and ketone bodies as an indicator for the energy deficit of pregnant ewes. An equation was designed to estimate the energy deficit of pregnant ewes based on the measured level of ketone bodies in the blood and a predetermined level of ketone bodies. Later on the level of ketone bodies was replaced by the level of beta-hydroxy-butyrate (Russel, 1984; 1985).

Theoretical estimation of the energy requirement of pregnant ewes is complicated by the low level of energetic efficiency of conceptus growth and the large variation in estimates of this efficiency (Rattray, 1974; Robinson et al., 1980). However, it is obvious that the energy requirement increases with the litter size of the ewes.

Dry matter intake of ewes with an intact fleece is depressed during the last weeks of pregnancy on diets of roughage supplemented with concentrates. This intake is more severely depressed in ewes with a litter size of more than two lambs (Everts, 1990). The high energy demand and the limited intake capacity in ewes with a large litter size causes an energy deficit at the end of pregnancy. Depending on the size of the energy deficit ewes may become acetonaemic. In a lot of experiments acetonaemia, induced by fasting, is studied. However, in most cases induced 
acetonaemia is a reversible process whereas acetonaemia in practice is not.

The optimum feeding strategy for ewes with a large litter size should result in a sufficient feed intake, a minimal incidence of acetonaemia and vital lambs at birth. Several feeding strategies were compared to the Dutch feeding standards for ewes with twins ( = treatment $\mathrm{L} 40 \mathrm{C}$ ) during six years. In the first and the second year the effect of a high feeding level during mid pregnancy (= treatment H40C) was studied. In the third and the fourth year the effect of a higher proportion of energy originating from concentrates at the end of pregnancy (= treatment L60C) and in the fifth and sixth year the effect of a higher proportion of energy from concentrates combined with a higher protein supply and a lower protein degradability at the end of pregnancy ( = treatment L60C + P) was studied. The characteristics of feed intake, incidence of acetonaemia and perinatal lamb mortality are reported in an earlier paper (Everts, 1990). The effects of the treatments on the pattern of some blood parameters (glucose, BHB and NEFA) were studied. With these blood parameters as indicators for the energy status it should be possible to estimate the energy requirement of ewes at the end of pregnancy.

\section{Materials and methods}

The design of the experiment, the age and breed of the ewes, the feeding regimes and the statistical analysis are described in a previous paper (Everts, 1990). Additionally blood samples are taken from the ewes with vacutainers from the jugular vene. Samples were taken prior to the morning feeding with minimal disturbance of the ewes. The days of sampling were day $28,56,84,105,119,126,133,138$ and 141 of pregnancy. The samples were centrifuged at $2{ }^{\circ} \mathrm{C}$ and the plasma was immediately analysed for glucose (Glucoquant, Boehringer Mannheim NV, Amsterdam), beta-hydroxy-butyrate (B-HB dehydrogenase, Boehringer Mannheim NV, Amsterdam) and NEFA (NEFA-C-test, Wako Pure Chemical Industries, Ltd, Osaka, Japan). Because of analytical problems the plasma samples from the first experiment were not analysed for beta-hydroxy-butyrate and NEFA. Also the samples from the second experiment were not analysed for NEFA.

\section{Results}

\section{Glucose}

Analysis of the plasma glucose levels with a model including year of experiment, litter size, age of the ewe, effect of acetonaemia and the effect of treatments (Everts, 1990) showed a low percentage of variance accounted for (5 to $37 \%$ ) and a high residual standard error $\left(0.24\right.$ to $\left.0.60 \mathrm{mmol} \mathrm{l}^{-1}\right)$. The lowest plasma glucose levels $\left(1.16 \mathrm{mmol} \mathrm{1}^{-1}\right)$ were observed in ewes with acetonaemia and the highest levels $\left(4.73 \mathrm{mmol} 1^{-1}\right)$ were observed in barren ewes. The plasma glucose showed for all litter sizes a rise at the end of pregnancy (day 141). The effect of age on plasma glucose is not very consistent. In the beginning and at the end of pregnancy older ewes ( $>2$ years) showed a tendency to have lower levels than younger ewes. Ewes suffer- 
H. EVERTS

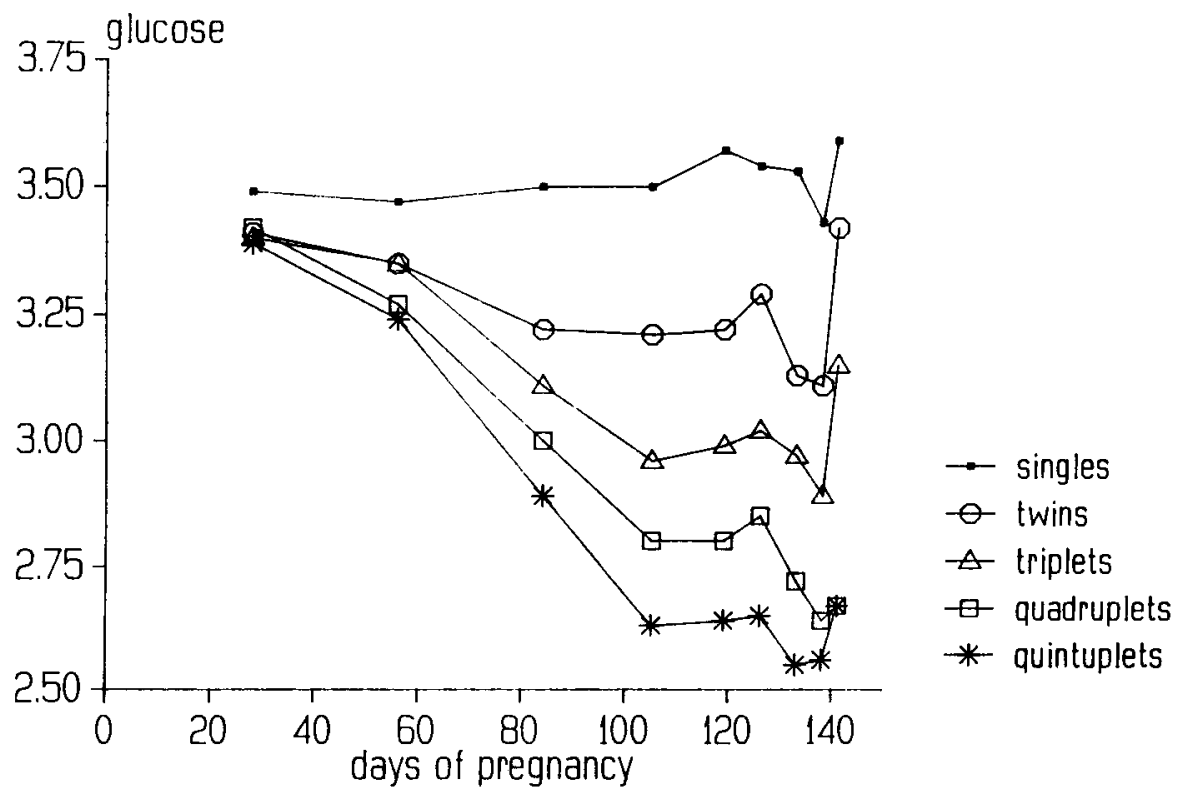

Fig. 1. The effect of litter size on plasma glucose level (mmol $1^{-1}$ plasma) during pregnancy for ewes of mean age and on the control treatment.

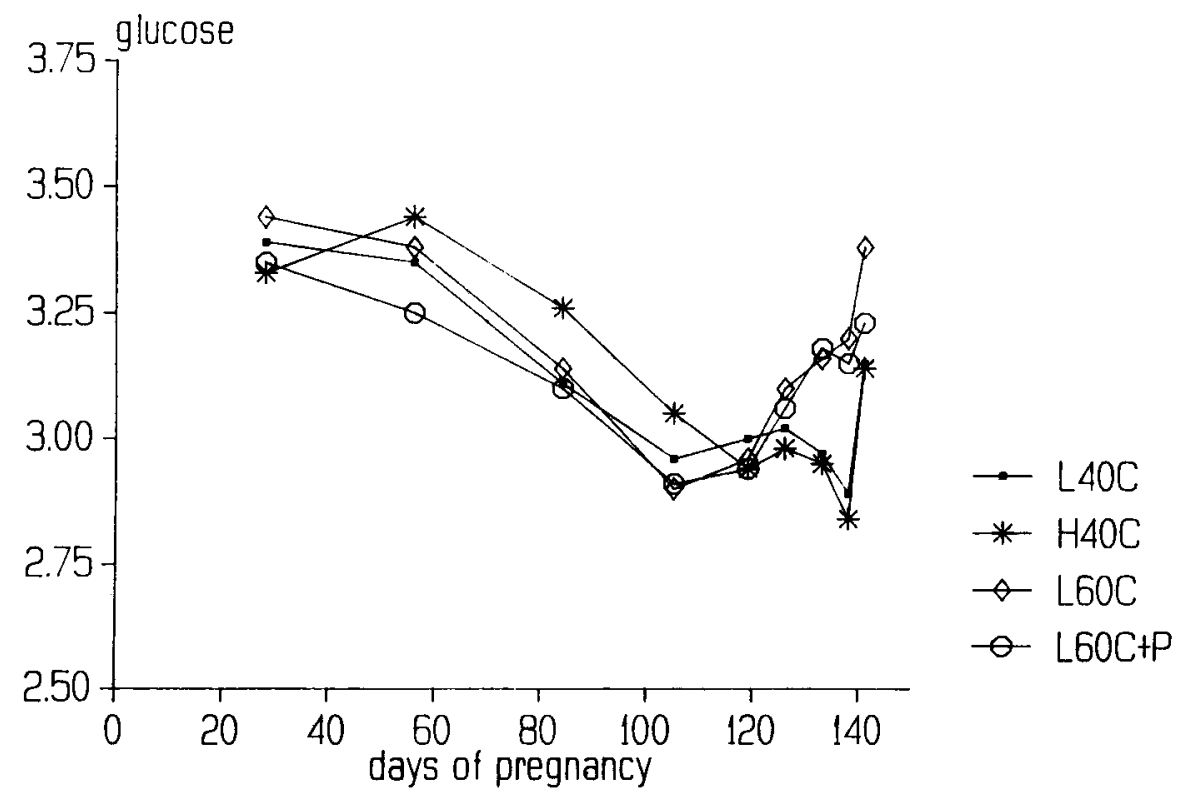

Fig. 2. The effect of treatment on plasma glucose level (mmol $1^{-1}$ plasma) during pregnancy for ewes of mean age and with a triplet. 
ing from acetonaemia had a significantly lower plasma glucose level. The difference at day 126 was $0.43 \mathrm{mmol}^{-1}(\mathrm{SD}=0.11)$ and at day $1380.81 \mathrm{mmol} \mathrm{l}^{-1}(\mathrm{SD}=$ $0.14)$.

In Figure 1 the effect of litter size on plasma glucose level is shown. From day 84 of pregnancy plasma glucose level was significantly affected by the litter size. The mean values for ewes with singles remained more or less constant at a level of about $3.4 \mathrm{mmol} \mathrm{l}^{-1}$, but the mean values for ewes with quintuplets decreased from 3.4 mmol $\mathrm{l}^{-1}$ at day 28 of pregnancy to $2.6 \mathrm{mmol} \mathrm{l}^{-1}$ at day 139 of pregnancy (Figure 1).

In Figure 2 the effect of the feeding treatment is shown. For treatment $\mathrm{H} 40 \mathrm{C}$ a positive effect of $0.16(\mathrm{SD}=0.05) \mathrm{mmol}^{-1}$ at mid pregnancy was observed and at the end of pregnancy (day 133 and day 138) treatment L60C and L60C $+\mathrm{P}$ showed a positive effect of $0.25(\mathrm{SD}=0.10) \mathrm{mmol} \mathrm{l}^{-1}$. At day 141 significant effects could not be proven due to the large variation.

\section{Beta-hydroxy-butyrate}

Analysis of the beta-hydroxy-butyrate ( $=\mathrm{BHB}$ ) levels in plasma using the same model as for glucose resulted in a percentage of variance accounted for between 5 and $50 \%$. The residual standard error increased from $0.05 \mathrm{mmol} \mathrm{l}^{-1}$ to $1.56 \mathrm{mmol}$ 1-1 during pregnancy. The lowest plasma level of BHB was observed in a non pregnant ewe $\left(0.18 \mathrm{mmol}^{-1}\right)$ and the highest level in a ewe suffering from acetonaemia $\left(8.81 \mathrm{mmol}^{-1}\right)$. The effect of age was not significant, but at the end of pregnancy older ewes $\left(>2\right.$ years) tended to higher BHB levels $\left(+0.5 \mathrm{mmol} \mathrm{l}^{-1}\right.$; $\mathrm{SD}=$ $0.3)$. Ewes suffering from acetonaemia had higher plasma BHB. The difference at day 199 was $0.53 \mathrm{mmol} \mathrm{l}^{-1}(\mathrm{SD}=0.07)$ and at day $1382.33 \mathrm{mmol} \mathrm{l}^{-1}(\mathrm{SD}=$ $0.33)$.

The effect of litter size was significant from day 84 of pregnancy untill the end of pregnancy. The increase of BHB level to the end of pregnancy was non linear for ewes with more than one lamb. The effect of litter size on the mean values of plasma BHB is shown in Figure 3.

The BHB plasma level was only in treatment $\mathrm{L} 60 \mathrm{C}+\mathrm{P}$ significantly affected at day 133 of pregnancy. It was $0.59 \mathrm{mmol} \mathrm{l}^{-1}(\mathrm{SD}=0.29)$ lower in the ewes on this treatment. At day 138 and day 141 it tended also to be about $0.50 \mathrm{mmol}^{-1}$ lower (not significant). Also the ewes on treatment L60C tended to be lower (not significantly) than the control treatment L40C (Figure 4).

\section{$N E F A$}

Analysis of NEFA levels in plasma with the same model as for glucose resulted in a similar range in percentage of variance accounted for as seen at the BHB levels, but the residual standard error was smaller $(0.09$ to 0.46$)$. The lowest value was observed in a barren ewe $\left(0.07 \mathrm{mmol} \mathrm{1}^{-1}\right)$ and the highest level in a ewe suffering from acetonaemia $\left(2.74 \mathrm{mmol}^{-1}\right)$. The age of the ewes affected the NEFA level significantly in the first months of pregnancy. In older ewes $(>2$ year) the NEFA 
H. EVERTS

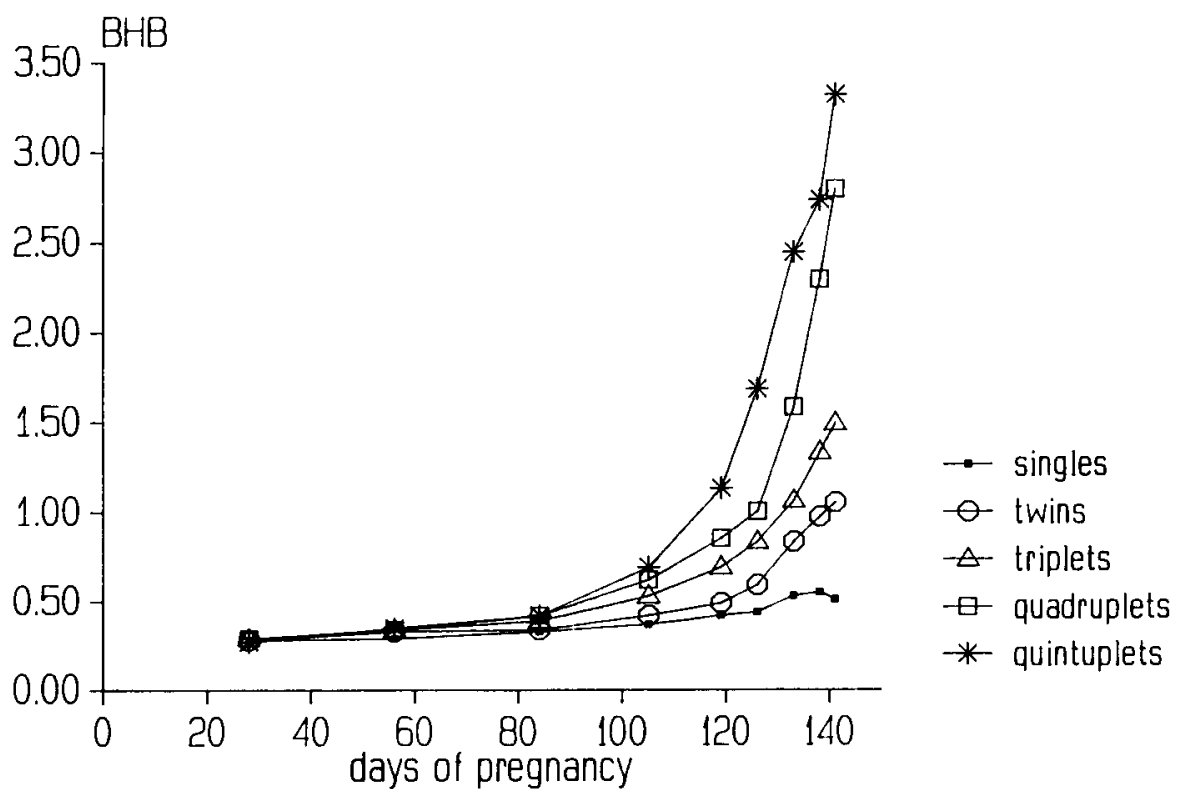

Fig. 3. The effect of litter size on plasma BHB level (mmol $1{ }^{1}$ plasma) during pregnancy for ewes of mean age and on the control treatment.

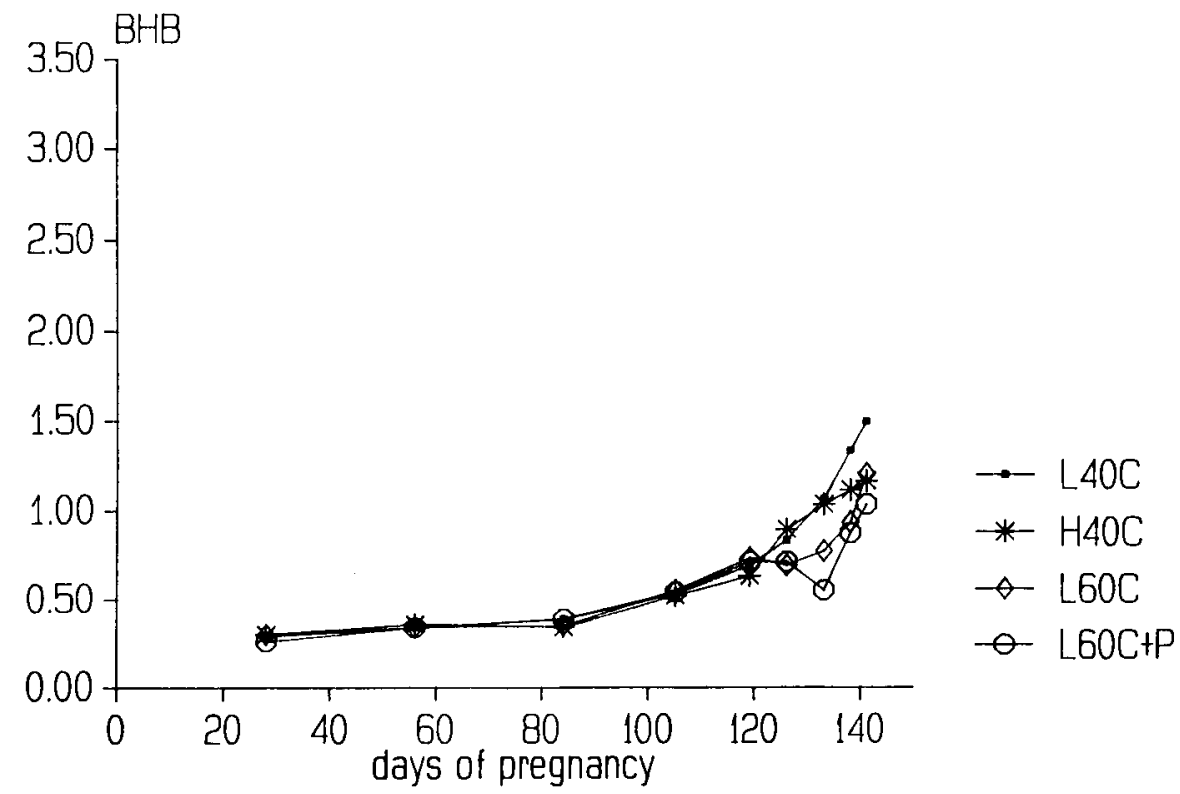

Fig. 4. The effect of treatment on plasma BHB level (mmol $\mathrm{l}^{-1}$ plasma) during pregnancy for ewes of mean age and with a triplet. 
level was $0.10 \mathrm{mmol}^{1-1}(\mathrm{SD}=0.03$ ) lower than in younger ewes. NEFA levels of ewes suffering from acetonaemia were higher. At day 119 the difference was 0.29 $\mathrm{mmol} \mathrm{l}^{-1}(\mathrm{SD}=0.06)$ and at day $1380.37(\mathrm{SD}=0.11)$.

A significant effect of litter size was seen from day 105 untill the end of pregnancy. Figure 5 shows the effects of litter size on the mean values of NEFA in the plasma. Ewes on treatment L60C $+\mathrm{P}$ had significantly lower NEFA levels than on the control treatment $\mathrm{L} 40 \mathrm{C}\left(-0.25 \mathrm{mmol}^{-1}\right.$; $\left.\mathrm{SD}=0.09\right)$. Ewes on treatment $\mathrm{L} 60 \mathrm{C}$ had only significantly lower NEFA levels at day 138 of pregnancy $(-0.23 \mathrm{mmol}$ $1^{-1}$; SD $=0.99$ ) (Figure 6).

\section{Relations between blood parameters and energy status}

In general a poor relation between $\mathrm{BHB}$ or NEFA in plasma and ME intake was observed. Only 20 to $30 \%$ of the variance of the plasma parameters was accounted for. Addition of litter size and the interaction between litter size and ME intake increased the percentage of variance accounted for to about $60 \%$. The regression coefficient of $\mathrm{ME}$ for ewes with singles and twins was not significantly different from zero, but for ewes with three or more lambs this coefficient was significantly lower then zero. This indicated that BHB and NEFA level in the plasma are related to the size of a negative energy balance (energy deficit of ewes with 3 or more lambs) and not to the size of a positive energy balance (energy surplus of ewes with one or two lambs).

Based on this analysis ewes were divided in two groups: one group of ewes with singles and twins (in most cases with an energy surplus; set A) and an other group of ewes with three or more lambs (in most cases with an energy deficit; set B). To estimate energy requirements for pregnant ewes, using predetermined plasma parameter levels, the following model was used:

$$
\mathrm{ME}_{\mathrm{i}}=\mathrm{ME}_{\mathrm{m}}+\mathrm{ME}_{\mathrm{c}}+\mathrm{B} \times \text { plasma parameter }
$$

where $\mathrm{ME}_{\mathrm{i}}=$ energy intake, $\mathrm{ME}_{\mathrm{m}}=$ energy for maintenance and $\mathrm{ME}_{\mathrm{c}}=$ energy for conceptus growth. When in this equation it is assumed that $\mathrm{ME}_{\mathrm{m}}$ is constant and that $\mathrm{ME}_{\mathrm{c}}$ is depending of the sum of birth weights of the born lambs (= SBW) then Equation 1 can be written as

$$
\mathrm{ME}_{\mathrm{i}}=\mathrm{C}+\mathrm{B}_{1} \times \mathrm{SBW}+\mathrm{B}_{2} \times \text { plasma parameter }
$$

The percentage of variance accounted for of the model according to Equation 2 was increased by including a factor for maternal growth.

The maternal growth was calculated as the body weight gain of the ewe during day 117 to day 141 of pregnancy minus $38 \%$ of the body weight loss at parturition (defined as body weight at day 141 minus body weight after lambing). This percentage of 38 was derived from data of McDonald et al. (1980). The use of occurence of acetonaemia as an additional variable in the model improved the percentage of variance accounted for in some cases. The results are given in Table 2 . In the regressions the mean level of energy intake and of the plasma parameter as observed during the last month of pregnancy were used. Replacing the mean values of the plasma 
H. EVERTS

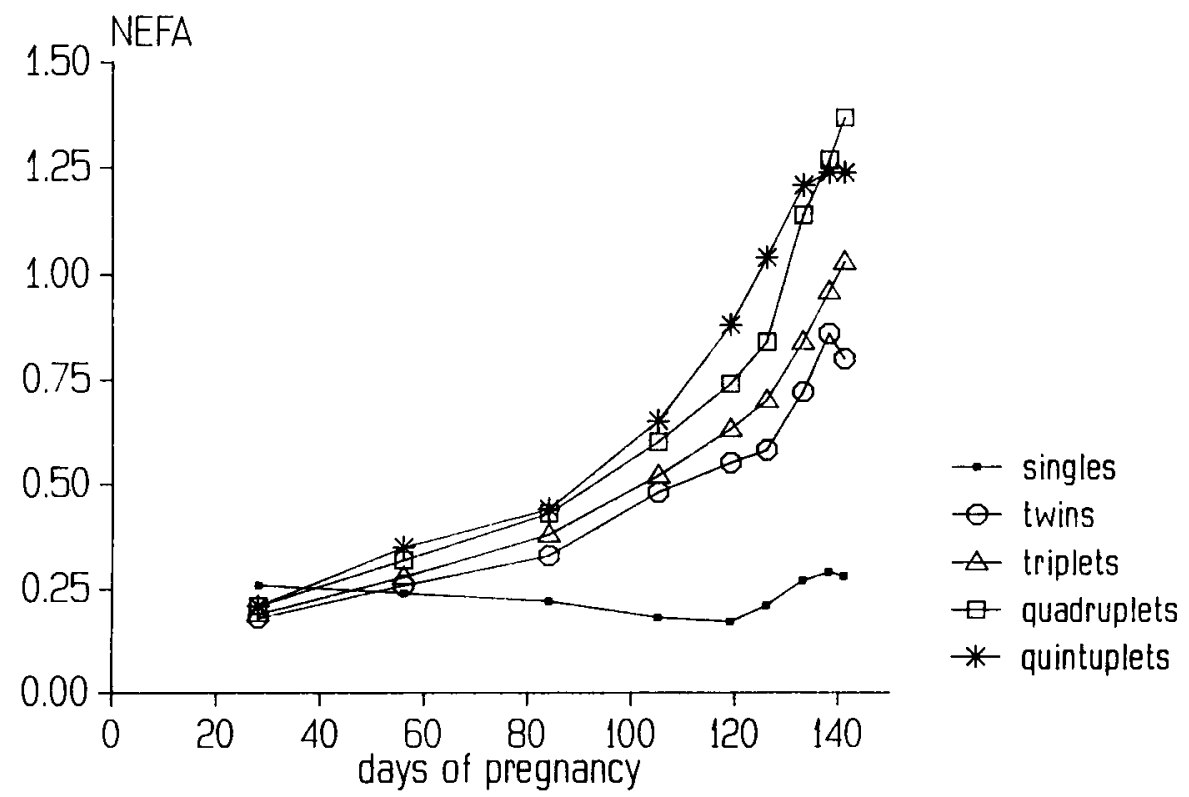

Fig. 5. The effect of litter size on plasma NEFA level ( $\mathrm{mmol} \mathrm{l}^{-1}$ plasma) during pregnancy for ewes of mean age and on the control treatment.

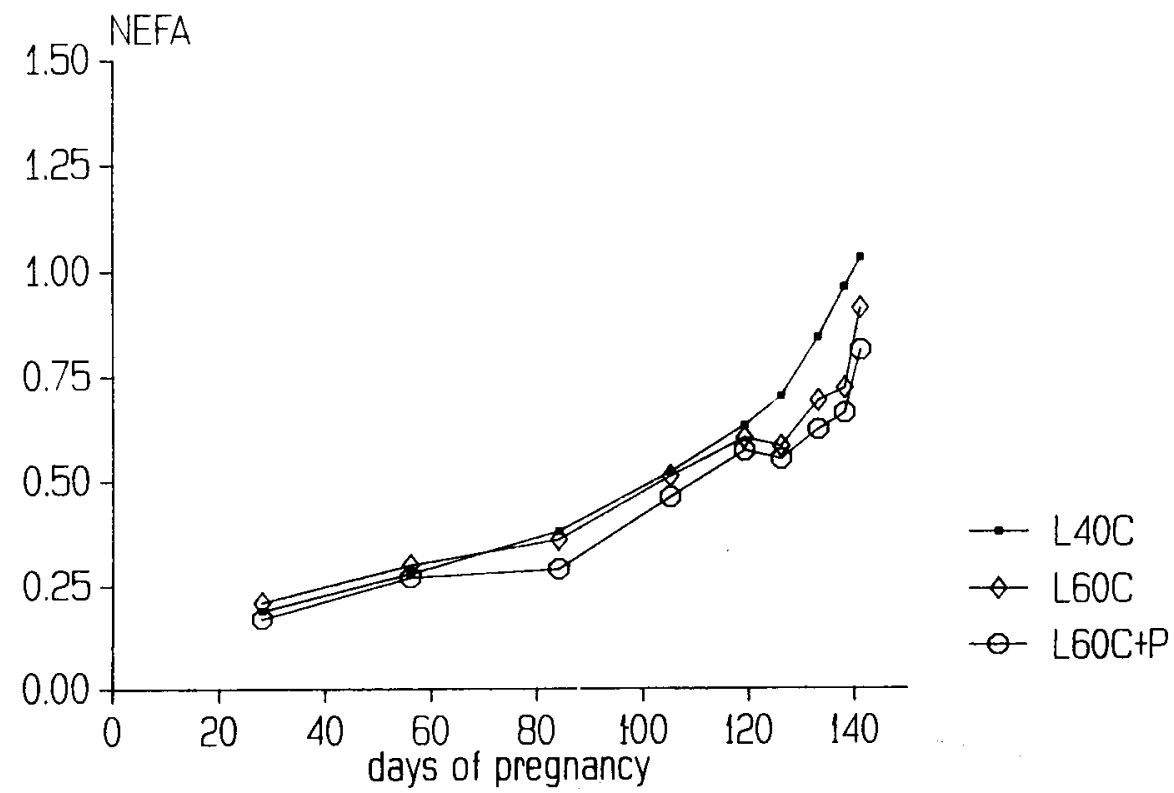

Fig. 6. The effect of treatment on plasma NEFA level (mmol 1-1 plasma) during pregnancy for ewes of mean age and with a triplet. 
Table 2. Relations between mean ME intake ( = MEX) in MJ and mean plasma parameter level in the blood (glucose $=$ GLUX, BHB = BHBX, NEFA = NEFAX), sum of birth weight (SBW), maternal growth (MATGR) and the incidence of acetonaemia (ACETON). The estimated coefficients with the SD between parenthesis, the percentage variance accounted for $(=\%$ Acc. $)$ and the RSD are shown. Set A are ewes with singles and twins and set $\mathrm{B}$ are ewes with triplets, quadruplets and quintuplets.

\begin{tabular}{|c|c|c|c|c|c|c|c|}
\hline & \multicolumn{5}{|c|}{ Estimated coefficients (SD) } & \multirow{2}{*}{\multicolumn{2}{|c|}{$\begin{array}{l}\% \\
\text { Acc. }\end{array}$}} \\
\hline & constant & $\mathrm{B}_{1}$ & $\mathrm{~B}_{2}$ & $\mathrm{~B}_{3}$ & $\mathrm{~B}_{4}$ & & \\
\hline \multicolumn{8}{|c|}{ Model: $M E X=$ constant $+B_{1} \times G L U X+B_{2} \times S B W+B_{3} \times M A T G R+B_{4} \times A C E T O N$} \\
\hline 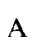 & $1.33( \pm$ & $3.23( \pm 0.81)$ & $0.52( \pm 0.08)$ & $11.87( \pm 2.75)$ & $-(-)^{\mathrm{a}}$ & 49.2 & 1.6 \\
\hline & 0.40( & $2.34( \pm 0.38)$ & $0.73( \pm 0.08)$ & $8.45( \pm 0.99)$ & $-1.40( \pm 0.50)$ & 62.2 & 1.6 \\
\hline \multicolumn{8}{|c|}{ Model: $M E X=$ constant $+B_{1} \times B H B X+B_{2} \times S B W+B_{3} \times M A T G R+B_{4} \times A C E T O N$} \\
\hline A & 12.74( & $017+3$ & $0.39( \pm 0$ & $9.47( \pm 3$ & $-(-)$ & 32.6 & 1.8 \\
\hline 3 & 9.23( & $-1.26( \pm 0.21)$ & $0.66( \pm 0.08)$ & $8.17( \pm 1.15)$ & $-(-)$ & 62.0 & 1.7 \\
\hline \multicolumn{8}{|c|}{ Model: $M E X=$ constant $+B_{1} \times N E F A X+B_{2} \times S B W+B_{3} \times M A T G R+B_{4} \times A C E T O N$} \\
\hline$A$ & 13.38( & -5 & 0.72 & 9.68 & - & 55.0 & \\
\hline$B$ & $10.71( \pm 1.01)$ & $-3.55( \pm 0.62)$ & $0.66( \pm 0.09)$ & $6.54( \pm 1.22)$ & $-1.74( \pm 0.51)$ & 66.7 & 1.6 \\
\hline
\end{tabular}

a Not included in the model.

parameters by the observed maximum or minimum levels gave no better results. In the model a linear relation between energy deficit and plasma parameters was assumed. But when the levels of BHB or NEFA are transformed in natural logarithms the percentage of variance accounted for did not increase.

With the regression equations of Table 2, energy requirements of pregnant ewes in the last month of pregnancy can be calculated. However, the setting of the predetermined levels of the blood parameters and the maternal gain need consideration. The maternal growth as calculated included the udder development. To prevent underestimation of the requirement maternal gain should be at least equal to the mass increase of the udder. Estimates for mass increase of the udder as given by Robinson et al. (1979) were used. The values for the sum of lamb birth weight were derived from the mean observed birth weights in this experiment (Everts, 1990). With the plasma values of the parameters as observed in the onset of pregnancy as a standard (glucose $=3.4 \mathrm{mmol} \mathrm{1}^{-1}$; $\mathrm{BHB}=0.3 \mathrm{mmol} \mathrm{l}^{-1}$; NEFA $=0.2$ $\mathrm{mmol} \mathrm{l}^{-1}$ ) the energy need of pregnant ewes was estimated (Table 3 ). These plasma parameter levels, combined with a zero lamb birth weight and no maternal growth, should result in an estimate of the energy requirement for maintenance (Table 3). However, in practice a moderate energy deficit is allowed and thus the predetermined levels of the blood parameters can be changed (glucose $=3.0 \mathrm{mmol} \mathrm{l}^{-1}$; BHB $=1.0 \mathrm{mmol}^{1-1}$; NEFA $=0.75 \mathrm{mmol}^{-1}$ ). The estimated energy requirements based on these values are shown in Table 3 . 


\section{H. EVERTS}

Table 3. Estimated energy requirement (MJ ME d-1) for maintenance and for pregnant ewes with 1 to 5 lambs during the last month of pregnancy. The regression equations from Table 2 are used with 2 predetermined levels of plasma parameters. The sum of lamb birth weights (SBW) for each litter size are observed means and the maternal growth equals to the udder development as estimated by Robinson et al. (1979).

\begin{tabular}{|c|c|c|c|c|c|c|c|c|c|c|}
\hline \multirow{2}{*}{$\begin{array}{l}\text { Litter } \\
\text { size }\end{array}$} & \multirow{2}{*}{$\begin{array}{l}\text { SBW } \\
(\mathrm{kg})\end{array}$} & \multicolumn{9}{|c|}{ Energy requirement (MJ $\mathrm{M} \mathrm{d}^{-1}$ ) } \\
\hline & & \multicolumn{3}{|c|}{ NEFA } & \multicolumn{3}{|l|}{ ВНВ } & \multicolumn{3}{|c|}{ Glucose } \\
\hline \multicolumn{2}{|c|}{ Level $\left(\mathrm{mmol} \mathrm{l}^{-1}\right)$} & \multicolumn{2}{|l|}{0.20} & \multirow{2}{*}{$\begin{array}{l}0.75 \\
\text { B }\end{array}$} & \multicolumn{2}{|l|}{0.30} & \multirow{2}{*}{$\begin{array}{l}1.00 \\
\text { B }\end{array}$} & \multicolumn{2}{|l|}{3.4} & \multirow{2}{*}{$\begin{array}{l}3.0 \\
\text { B }\end{array}$} \\
\hline Equati & n set & A & B & & A & $\mathrm{B}$ & & A & B & \\
\hline Maintena & nce ${ }^{1}$ & 12.2 & 10.0 & & 12.8 & 8.9 & & 12.3 & 8.3 & \\
\hline 1 lamb & 5.0 & & 13.8 & 11.8 & & 12.7 & 11.8 & & 12.6 & 11.6 \\
\hline 2 lambs & 9.0 & & 16.5 & 14.6 & & 15.5 & 14.7 & & 15.6 & 14.7 \\
\hline 3 lambs & 10.5 & & 17.7 & 15.8 & & 16.8 & 15.9 & & 16.9 & 16.0 \\
\hline 4 lambs & 12.0 & & 18.9 & 17.0 & & 18.0 & 17.1 & & 18.3 & 17.4 \\
\hline 5 lambs & 12.5 & & 19.6 & 17.6 & & 18.7 & 17.8 & & 19.1 & 18.1 \\
\hline
\end{tabular}

1 With a birth weight of lambs of zero and no maternal gain assumed.

\section{Discussion}

\section{Levels of the blood parameters}

The observed plasma glucose levels at the end of pregnancy are in line with levels reported by Davies et al. (1971), Ranaweera et al. $(1979,1981)$ and Rémésy \& Demigné (1979). Blood glucose levels as shown by Austin \& Wilde (1985) and Stern et al. (1979) are lower. In a limited number of blood samples with 2.8 to $3.6 \mathrm{mmol}$ glucose per litre plasma we confirmed that blood glucose level was 20 to $25 \%$ lower than the plasma glucose level. Low levels of glucose as observed in the plasma of ewes suffering from acetonaemia were also shown by Rémésy \& Demigné (1979) in ewes suffering from acetonaemia and by Ranaweera et al. $(1979,1981)$ in ewes suffering from acetonaemia induced by starvation. Low blood glucose levels in ewes suffering from acetonaemia were reported by Andrews (1982) and Wierda et al. (1985).

At day 141 of pregnancy the glucose level is less reliable, probably due to the stress of the lambing process. Blood samples were taken with minimal disturbance of the ewes, but the young ewes had at the first blood sampling a higher glucose level than older ewes. It is unlikely that this difference is due to a real age effect. Probably, young ewes were not sufficiently accustomed to the procedure of blood sampling.

Comparison of the levels of BHB in our experiment with level of ketone bodies from other experiments is rather difficult due to the lack of a simple conversion factor. Bouchat et al. (1981) showed that the concentration of ketone bodies and the ratio between $\mathrm{BHB}$ and aceto-acetate is influenced by the time of fasting. Thus ke- 
tone bodies level can only be expressed in a BHB level when the ratio between the different ketone bodies is known.

The observed levels of BHB in the plasma are comparable to levels reported by Rémésy \& Demigné (1979) and Austin \& Wilde (1985). However, we observed some very high levels in ewes suffering from acetonaemia. The analysis of our samples containing a very high level of BHB can be less accurate due to insufficient dilution.

The NEFA levels as shown in Figure 5 correspond to the BHB levels, but the increase at the end of pregnancy is less dramatic in ewes with a large litter size. The levels in ewes without acetonaemia are in line with levels as observed by Rémésy \& Demigné (1979), Davies et al. (1971) and Stern et al. (1979). The levels of ewes with acetonaemia are higher than reported by Rémésy \& Demigné (1979), but in the same range as shown by Wierda et al. (1985). The effect of age can be explained in the same way as for the glucose.

\section{Effect of treatment and acetonaemia}

The pattern of energy intake was described in a previous paper (Everts, 1990). The higher energy intake during mid pregnancy on treatment $\mathrm{H} 40 \mathrm{C}$ was reflected in a higher glucose level, but not in the BHB level. The plasma samples of the ewes on treatment $\mathrm{H} 40 \mathrm{C}$ were not analysed for NEFA. At the end of pregnancy there was a higher energy intake for ewes on treatment $\mathrm{L} 60 \mathrm{C}$ and $\mathrm{L} 60 \mathrm{C}+\mathrm{P}$. The level of glucose was significantly higher for ewes on treatment $\mathrm{L} 60 \mathrm{C}$ and $\mathrm{L} 60 \mathrm{C}+\mathrm{P}$. At the same period BHB and NEFA levels were lower for ewes on treatment L60C and L60C $+\mathrm{P}$. The lower BHB level was somewhat more pronounced in treatment L60C + P. The higher glucose, the lower BHB and lower NEFA levels of the ewes on the treatment $\mathrm{L} 60 \mathrm{C}$ and $\mathrm{L} 60 \mathrm{C}+\mathrm{P}$ indicated a better energy status for these ewes. A lower incidence of acetonaemia was expected for ewes on treatment L60C and $\mathrm{L} 60 \mathrm{C}+\mathrm{P}$, but this was not observed. Probably a severe energy deficit is not the only cause for acetonaemia. Watsney et al. (1982) could detect ewes sensitive for acetonaemia using the intravenous glucose tolerance test. They suggested that a poor control of the glucose homeostasis is a predisponing factor for acetonaemia.

\section{Prediction of the energy requirements}

In our experiment the significant effect of litter size on the glucose level indicated that the glucose concentration was related to the energy or glucose deficit in ewes with a large litter size. Also the significant effects of treatments support this. However, Russel (1977) did not prefer glucose as an index for energy status, because peripheral glucose concentration is homeostatic controlled and quickly responding to adrenal cortical hyperactivity. The first objection against glucose as an index for energy status is probably only valid for ewes with about the same litter size.

The BHB level as an index for energy status can be biassed by BHB originating from rumen fermentation (Russel, 1977). Mantson et al. (1981) reported a wide variation in the BHB level in cows during the day. Rémésy \& Demigné (1979) observed lower levels of BHB prior to feeding than three hours after feeding on a high feeding 


\section{H. EVERTS}

level. But when the feeding level was restricted severely, they observed a decrease in BHB after feeding. This suggested only a minor contribution of BHB from the rumen fermentation when the ewe mobilizes fat. This can also be seen from the coefficients for $\mathrm{BHB}$ in the equations of Table 2. In set $\mathrm{A}$ with singles and twins this coefficient is close to zero with an extreme large standard error and in set B with ewes with more than 2 lambs the coefficient is negative with a relative small standard error.

The NEFA level did not increase above a value of about $2.5 \mathrm{mmol}^{-1}$, while the $\mathrm{BHB}$ in the same ewes increased to much higher levels. This plateau of NEFA at high levels of undernutrition is seen as an disadvantage of NEFA as an index for energy deficit (Russel, 1977). The discrepancy between NEFA and keton bodies was also observed by Patterson (1966) in ewes with pregnancy acetonaemia.

The equation to predict the energy requirement derived from the data of ewes with singles and twins (set A) shows a relative low percentage of variance accounted for. The prediction of the maintenance requirement in Table 2 (set A) is high (about $12 \mathrm{MJ} \mathrm{ME}$ ) in relation to a body weight of 85 to $90 \mathrm{~kg}$. The coefficient for $\mathrm{BHB}$ in set $\mathrm{A}$ is not significant. The coefficients for glucose and NEFA in set $\mathrm{A}$ are showing a higher standard deviation than in set $\mathrm{B}$. The estimate for the energy demand for conceptus growth is rather variable ( 0.39 to $0.72 \mathrm{MJ}$ ME per kg of born lamb). The calculated maternal growth required between 9.5 and $11.9 \mathrm{MJ} \mathrm{ME}$ per kg gain. These equations indicate an unsuccesfull way to estimate energy requirements. This failure was mainly due to the lack of ewes with a negative energy balance.

The equations derived from ewes with more than two lambs (set B) gave better results. The estimate for maintenance was between 8.4 and 10.0 MJ ME. The estimate for the energy demand for conceptus growth was about $0.7 \mathrm{MJ} \mathrm{ME} \mathrm{per} \mathrm{kg}$ of born lamb. According to McDonald et al. (1979) about $110 \mathrm{~kJ}$ per day per $\mathrm{kg}$ of born lamb is stored in the uterus during the last month of pregnancy. This resulted in an estimate of 0.16 for the energetic efficiency of conceptus growth, which is in line with the estimates of Robinson et al. (1980). The presented figure of $0.7 \mathrm{MJ}$ ME per $\mathrm{kg}$ of born lamb is lower than the figure of Russel (1967), but he calculated also a net efficency of 0.07 . The introduction of the calculated maternal growth improved the equation. This might indicate a mobilization of maternal body protein. This idea was supported by the low energy content of maternal growth as shown in the coefficient of ME for maternal growth $\left(B_{3}\right)$. Guada et al. (1976) suggested an increased maternal body protein catabolism to provide energy for the rapid growing foetuses. This was based on a higher correlation between foetal load and plasma urea than between foetal load and plasma glucose or NEFA.

To predict energy requirements for ewes with a large litter size, the equations of set B were used with predetermined levels of glucose, BHB and NEFA as observed at the onset of pregnancy. The requirement based on NEFA as indicator was the highest and the requirement based on BHB as indicator the lowest. The mean of the three used indicators showed an energy requirement for pregnant ewes with a body weight of about $85 \mathrm{~kg}$ in the last month of pregnancy of $9.1 \mathrm{MJ}$ plus $0.78 \mathrm{MJ} \mathrm{ME}$ per $\mathrm{kg}$ of born lamb including the ME for udder development.

In practice a moderate energy deficit can be allowed. Russel (1984) used the limit 
of $0.8 \mathrm{mmol} \mathrm{l}^{-1}$ for a flock under field conditions and a limit of $1.1 \mathrm{mmol}^{-1}$ for individually fed ewes under experimental conditions. Our choice for a limit of 1 mmol $1^{-1}$ is in line with these recommended limits. The limit for NEFA was 0.75 mmol $1^{-1}$ and should represent a moderate level of undernourishment (Russel, 1977). The limit of $3 \mathrm{mmol}^{-1}$ for glucose was derived from the mean level of ewes with triplets. When these lower 'minimum' requirements are used, the energy deficit must be compensated later on. The effect of crude protein intake and the crude protein requirement was not calculated due to a high correlation between energy intake and protein intake in the last phase of pregnancy $(r=0.921)$. However, it was clear that at least the combination of a high protein level and a low degradability of the protein had a positive effect on the birth weight of lamb. The effect of a higher energy supply on lamb birth weight must be small due to the low efficiency of conceptus growth (Rattray, 1974; Robinson et al., 1980).

\section{Conclusions}

At the end of pregnancy blood plasma parameters (glucose, BHB and NEFA) are affected by the litter size and the occurence of acetonaemia. The patterns of the mean values correspond with each other and are related to the ME intake, when litter size is taken into account. Treatment effects of a higher energy intake (ration with $60 \%$ of the energy originating from concentrates) showed better plasma levels. However, also on these treatments still cases of acetonaemia were observed. Beside energy deficit other unknown factors must be present to induce acetonaemia. The estimated energy requirements for ewes with a body weight of $85 \mathrm{~kg}$ in the last month of pregnancy were 13.0, 15.9, 17.1, 18.4 and 19.1 MJ ME per day for ewes with singles, twins, triplets, quadruplets and quintuplets, respectively. In practice a moderate energy deficit can be allowed. The estimated requirements can be lowered with about $10 \%$, but the energy deficit must be compensated later on.

\section{References}

Andrews, A. H., 1982. Effects of glucose and propylene glycol on pregnancy toxaemia in ewes. Veterinary Record 110: 84-85.

ARC, 1980. The nutrient requirements of farm livestock No. 2. Ruminants. Agricultural Research Council, 2nd edition, London, p. 115-116.

Austin, A. R. \& R. M. Wilde, 1985. The effect of sodium monensin on pregnant ewes. British.Veterinary Journal 141: 628-634.

Bouchat, J.-Cl., F. Doize \& R. Paquay, 1981. Influence of diet and prolonged fasting on blood lipids, ketone bodies, glucose and insulin in adult sheep. Réprodution, Nutrition, Développement 21: 69-81.

Bowden, D. M., 1971. Non-esterified fatty acids and ketone bodies in blood as indicators of nutritional status in ruminants: a review. Canadian Journal of Animal Science 51: 1-13.

CVB, 1988. Short table on feeding standards for farm animals and nutritive value of feedstuffs. (In Dutch.) Centraal Veevoederbureau in Nederland, Lelystad. p. 14.

Davies, P. J., R. G. Johnston \& D. B. Ross, 1971. The influence of energy intake on plasma levels of glucose, non-esterified fatty acids and acetone in the pregnant ewe. Journal of Agricultural Science (Cambridge) 77: 261-265.

Everts, H., 1990. Feeding strategy for pregnant ewes with large litter size. 1. Effect of quantity and composition of concentrates on intake and reproductive performance. Netherlands Journal of Agricultural Science 38: 527-540.

Netherlands Journal of Agricultural Science 38 (1990) 


\section{H. EVERTS}

Guada, J. J., J. J. Robinson \& C. Fraser, 1976. The effect of a reduction in food intake during late pregnancy on nitrogen metabolism in ewes. Journal of Agricultural Science (Cambridge) 86: 111-116.

INRA, 1988. Tables de l'alimentation des bovins, ovins \& caprins. Institute Nationale de la Recherche Agronomique, Paris, France, p. 75.

MAFF, 1975. Energy allowance and feeding systems for ruminants. Technical Bulletin 33, Ministry of Agriculture, Fisheries and Food, Department of Agriculture and Fisheries for Scotland and Department of Agriculture for Nothern Ireland. Her Majesty's Stationary Office, London, p. 44-46.

Mantson, R., G. J. Rowlands, W. Little \& K. A. Collis, 1981. Variability of blood composition of dairy cows in relation to time of day. Journal of Agricultural Science (Cambridge) 96: 593-598.

McDonald, I., J. J. Robinson, C. Fraser \& R. I. Smart, 1979. Studies on reproduction in prolific ewes. 5. The accretion of nutrients in the foetuses and adnexa. Journal of Agricultural Science (Cambridge) 92: 591-603.

NRC, 1985. Nutrient requirements of sheep. National Research Council, Subcommittee on sheep nutrition. National Academy Press, Washington DC, 6th revised edition, p. 45-49.

Patterson, D. S. P., 1966. Depôt fat mobilization and liver lipogenesis and ketogenesis in ovine pregnancy toxaemia and the effects of corticotrophin administration. Research in Veterinary Science 7: 484-492.

Ranaweera, A., E. J. H. Ford \& J. Evans, 1981. Gluconeogenesis from glycerol by ketotic sheep pregnant with twins. Research in Veterinary Science 30: 303-308.

Ranaweera, A., E. J. H. Ford \& A. R. Samad, 1979. The effect of triamcinolone acetonide on plasma glucose and ketone concentration and the total entry rate of glucose in twin pregnant hypoglycaemic ketotic sheep. Research in Veterinary Science 26: 12-16.

Rattray, P. V., 1974. Energy requirements for pregnancy in sheep. Proceedings of the New Zealand Society for Animal Production 34: 67-77.

Rémésy, C. \& C. Demigné, 1979. Effects of undernutrition during late pregnancy on gluconeogenesis and ketogenesis in twin pregnant ewes. Annales de Biologie Animale, Biochemique et Biophysique 19: 241-250.

Robinson, J. J., 1. McDonald, C. Fraser \& J. G. Gordon, 1980. Studies on reproduction in prolific ewes. 6. The efficiency of energy utilisation for conceptus growth. Journal of Agricultural Science (Cambridge) 94: 331-338.

Robinson, J. J., I. McDonald, I. McHattie \& K. Pennie, 1978. Studies on reproduction in prolific ewes. 4. Sequential changes in the maternal body during pregnancy. Journal of Agricultural Science (Cambridge) 91: 291-304.

Russel, A. J. F., 1977. The use of measurements of energy status in pregnant ewes. In: D. Lister (Ed.), Blood Profiles in Animal Production. Occasional publication No. 1, p. 31-39. British Society of Animal Production.

Russel, A. J. F., 1984. Means of assessing the adequacy of nutrition of pregnant ewes. Livestock Production Science 11: 429-436.

Russel, A. J. F., 1985. Nutrition of the pregnant ewe. In Practice (Suppl. Veterinary Record) 7: 23-25.

Russel, A. J. F., F. M. Doney \& R. L. Reid, 1967. Energy requirements of the pregnant ewe. Journal of Agricultural Science (Cambridge) 68: 359-363.

Sheehan, W., M. J. Lawlor \& 1. H. Bath, 1977. Energy requirements of the pregnant ewe. Irish Journal of Agricultural Research 16: 233-242.

Shevah, Y. \& W. J. M. Black, 1975. Differences in feed intake and performance of Finn Dorset ewes during the late pregnancy. Animal Production 20: 391-400.

Stern, D., J. H. Adler, H. Tagari \& E. Eyal, 1979. Responses of dairy ewes before and after parturition to different nutrional regimes during pregnancy. III. The concentration of some metabolites in the blood during pregnancy. Annales de Zootechnique 38: 239-250.

Wastney, M. E., A. C. Arcus, R. Bickersstaffe \& J. E. Wolff, 1982. Glucose tolerance in ewes and susceptibilty to pregnancy toxaemia. Australian Journal of Biological Science 35: $381-392$.

Wierda, A., J. Verhoeff, S. van Dijk, J. Dorresteijn \& T. Wensing, 1985. Effects of trenbolone acetate and propylene glycol on pregnancy toxaemia in ewes. Veterinary Record 116: 284-287. 